\title{
New anti HCV drugs in the pipeline
}

\author{
Marc Bourlière \\ From $16^{\text {th }}$ International Symposium on HIV and Emerging Infectious Diseases \\ Marseille, France. 24-26 March 2010
}

Several novel therapeutic approaches are currently in the pipeline for HCV treatment. They include new target host immune system as novel interferon, toll-like receptor agonists, therapeutic vaccines or interleukins, new target cell replication drug as ribavirin analogues, cyclophilin inhibitors, alpha glucosidase inhibitors, dephosphorylationinhibitors of eukaryotic initiation factors 2alpha, antisense molecule, entry inhibitors and specifically targeted antiviral therapy (STAT-C) such as viral enzyme inhibitor ( protease and polymerase). Several STAT-C molecules are currently in development and will soon be at hand and will offer new treatment opportunities to patients infected with hepatitis C. Promising results leading to more than $70 \%$ of sustained virological response in genotype 1 naïve patients have been reported with two proteases inhibitors (telaprevir and boceprevir) in combination with pegylated interferon and ribavirin that are currently in phase III. These studies also demonstrated the potential to shorten treatment duration in those with a rapid viral response and the realistic hope for retreatment success (40 and 75\%) in previous non responders or relapsers to interferon based therapies. In addition there is early indication that STAT-C drugs may help to overcome negative host factors that have historically been associated with poor response rates (such as ethnicity, insulin resistance, steatosis and cirrhosis). However these trials also emphasize the limitations of protease inhibitors and viral resistance data have provided important new lessons for small molecule drug development. In the near feature, it is likely that IFN-based therapy plus ribavirin will remain the backbone of the treatment of chronic hepatitis $C$. PEG-IFN and ribavirin are needed in order to prevent $\mathrm{HCV}$ resistance to STAT-C drugs and subsequently increase SVR. Genotypic and phenotypic resistance tests will also enter the therapeutic arena. Once several STAT-C agents without cross resistance become

\footnotetext{
Department of Hepato-Gastrenterology, Hôpital Saint Joseph. Marseille,
} France available, treatment strategies will include a combination of several drugs with different mechanisms of action (protease inhibitors and polymerase inhibitors) that could hopefully results in IFN and/or ribavirin sparing regimen. The first dual - combination clinical trial with oral antiviral is still ongoing. Patients receiving this combination for 14 days had undetectable HCV RNA in $63 \%$ of naïve genotype 1 patients. This "early success" has moved IFN-free regimen a step closer to reality for patients. In the future, there might be combinations of antivirals having additive potency, lacking cross resistance and with a good safety profile.

Published: 11 May 2010

doi:10.1186/1742-4690-7-S1-I24

Cite this article as: Bourlière: New anti HCV drugs in the pipeline. Retrovirology 2010 7(Suppl 1):124.

Submit your next manuscript to BioMed Central and take full advantage of:

- Convenient online submission

- Thorough peer review

- No space constraints or color figure charges

- Immediate publication on acceptance

- Inclusion in PubMed, CAS, Scopus and Google Scholar

- Research which is freely available for redistribution

Submit your manuscript at www.biomedcentral.com/submit 